\title{
Porcine Circovirus 2: Immunopathogenesis and Recent Developments in Vaccines
}

\author{
Abelardo Silva Júnior ${ }^{1,2^{*}}$, Otávio Valério de Carvalho ${ }^{1}$, Luiz Henrique Silva Bulos ${ }^{1}$, \\ Juliana Lopes Rangel Fietto ${ }^{2}$, Mauro Pires Moraes ${ }^{3}$, Márcia Rogéria de Almeida ${ }^{2}$ \\ ${ }^{1}$ Animal Virology Laboratory, Veterinary Department, Federal University of Viçosa, Viçosa, Brazil; ${ }^{2}$ Molecular Animal Infectology \\ Laboratory, Applied Biotechnology Institute (BIOAGRO), Federal University of Viçosa, Viçosa, Brazil; ${ }^{3}$ Plum Island Animal Dis- \\ ease Center, New York, USA. \\ Email: *abelardo.junior@ufv.br
}

Received March 6 ${ }^{\text {th }}, 2012$; revised April $7^{\text {th }}, 2012$; accepted May 5 ${ }^{\text {th }}, 2012$

\begin{abstract}
Porcine circovirus 2 (PCV2) is currently considered an important etiologic agent of swine and its infection has potentially serious economic impact on the swine industry worldwide. This virus is frequently associated with postweaning multisystemic wasting syndrome (PMWS), and also with other clinical conditions such as porcine dermatitis and nephropathy syndrome (PDNS), late-term abortions, reproductive failure in sows, proliferative and necrotizing pneumonia and congenital tremors. The term porcine circovirus-associated disease (PCVAD) is currently used to refer to any of these diseases when they are associated with PCV2 infection. The PCV2 was recognized as a pathogen in 1997, and many questions regarding its biology and pathogenesis remain unanswered. Currently, some studies have shown the production of new vaccine candidates and field efficacy testing of commercial vaccines. This review discusses some major points concerned with immunopathogenesis and vaccines for PCV2 infection.
\end{abstract}

Keywords: Porcine Circovirus 2; Vaccine; Immunopathogenesis

\section{Introduction}

Porcine circovirus (PCV) is a small, non-enveloped virus (17 $\mathrm{nm}$ in diameter), belonging to the genus Circovirus of the Circoviridae family. This virus has single-stranded circular DNA of approximately $1.76 \mathrm{~kb}$ [1]. The PCV genome has three main open reading frames (ORFs) that encode well characterized proteins: ORF1 encodes the viral replicase proteins REP and REP'; ORF2 encodes the viral capsid protein; and ORF3 encodes a protein which leads to cellular apoptosis, which is essential for the development of the viral pathogenesis [2-4]. Two species of PCV have been characterized, PCV1 and PCV2. Although PCV1 was initially described as an infectant of porcine kidney cell line (PK15), it shows no pathogenic traits [5]. On the other hand, PCV2 is the major causative agent of the multifactorial disease postweaning multisystemic wasting syndrome in pigs (PMWS). Additional factors besides the presence of PCV2, such as concomitant infections with other agents, genetic predisposition of the host, alterations of the immune system, are essential for the clinical disease development [6]. Other diseases, such as porcine dermatitis and nephropathy syndrome (PDNS),

"Corresponding author. proliferative and necrotizing pneumonia (PNP), perinatalmyocarditis and reproductive failures are also associated with PCV2 [7]. The term porcine circovirus-associated disease (PCVAD) is currently used to refer to any of these diseases when they are associated to PCV2 [8].

Based on phylogenetic studies, a study proposed a classification model for PCV2 [9]. This classification divides the virus lines into two major groups (1 and 2), which are subcategorized into subgroups from $1 \mathrm{~A}$ to $1 \mathrm{C}$, and from 2A to 2E. Several studies have demonstrated that the isolates from animals with PMWS are more often included in Group 1, whereas the isolates from animals without this disease are frequently included in Group 2 [10-12].

PCV2 associated porcine diseases are considered important and have potentially serious economic impact on the swine industry worldwide [13-15]. PCV2 viral particles are very stable and are able to persist in the environment of infected herds, making virus eradication very difficult [16]. For disease control, alternative strategies should therefore be investigated, and immune prophylaxis could be a great strategy. The high amino acid conservation degree between structurally deduced proteins among different PCV2 isolates should allow for the de- 
velopment of a monotypic vaccine approach.

Some vaccines for PCV2 are currently being tested, while others are in use in Europe, North America and more recently in Brazil. The available vaccine formulations consist of inactivated virus [17], Cap protein expressed in baculovirus system [18] and chimeric virus containing the portion of the immunogenic cap gene of PCV2 inserted into the PCV1 genome [19]. This review is a summary of recent results of immunopathogenesis and vaccines related to PCV2 in experimental stages and commercial vaccines.

\section{Immunopathogenesis}

PCV2 infection leads to host immunosuppression. The related lesions are characterized as lymphoid depression and granulomatous inflammation [20]. Hematological examination shows an expressive reduction of $\mathrm{T}$ CD4 ${ }^{+}$ lymphocytes, dendritic cell, NK cells, $\gamma \delta$ T cells, and B cells [21-23]. The mRNA levels of IL-1 $\alpha$ and IL-10 increase in affected animals, while IL-2 and IL-2R $\alpha$ (CD25) mRNA appear to decline [24]. The analysis of the cellular kinetic showed a lymphopenia due to decline of $\mathrm{B}$ CD2 $1^{+}$lymphocytes and T CD3 ${ }^{+}$cells. All subpopulation of the lymphocytes Th of the memory $\mathrm{CD}^{+} \mathrm{CD}^{+} \mathrm{CD} 8^{+}$, Th naive $\mathrm{CD}^{+} \mathrm{CD}^{+} \mathrm{CD}^{-}$cells, $\mathrm{Tc}^{\mathrm{CD}}{ }^{+} \mathrm{CD} 4^{-} \mathrm{CD} 8^{+}$cells and $\gamma \delta \mathrm{TCR}^{+} \mathrm{CD}^{+} \mathrm{CD} 4^{-} \mathrm{CD} 8^{-}$cells were susceptible to PCV2 infection. The NK, $\mathrm{CD}^{-} \mathrm{CD}^{-} \mathrm{CD}^{+}$cells also declined in PMWS affected animals [25].

Researchers showed that one of the five oligonucleotides selected from the PCV2 genome contained the CpG motives and showed inhibitory activity against the production of INF- $\alpha$ by the peripheral blood mononuclear cells [15]. Other study found a decline in the production of IFN- $\gamma$ in the peripheral blood cells [24]. However, stimulation of PK-15 and 3D4/31 cells with IFN- $\alpha$ and $\gamma$ before and during infection with PCV2 has led to increased PCV2 titers [26,27]. More research is required to clarify the role of IFNs in the pathogenesis of PCV2. A wide inhibition spectrum was detected, affecting the response induced by the receptor antagonists toll-like TLR7 and TLR9, indicating that the DNA of PCV2 can induce a negative dominant signal capable of influencing the recognition pattern of the cascade of activations of the inducible receptors [28].

The profile of the PDNS induced systemic expression of the cytokines in swine also has been investigated. In ill animals, a significant increase of the expression of mRNA codifiers of the proinflammatory cytokines IL- $1 \alpha$ and IL6 was observed [29]. The expression of MCP-1 and MIP1 was detected preceding the granulomatosa inflammation, thus suggesting that these cytokines could have a central role in the mediation of the granulomatosa inflammation in PCV2 infected lymphoids [30].
The lymphoid depletion can result from the viral replication in the lymph tissues or from the virus induced cellular apoptosis. The extent of lymphoid depletion had a direct correlation with the amount of PCV2 antigen in tissues [21,23,31]. However, the mutant viruses that do not express the protein codified by ORF3 do not induce visible lesions, but efficiently replicate in vitro and in mice. The super regulation of caspases and apoptotic promoters was detected in the infected mice suggesting that the PCV2 could induce apoptosis mediated by activation of caspases 8 and 3 [3,4,32].

The functional failure of alveolar macrophages, including a transient decline of phagocytes and a persistent decline in the microbiocidal capacity can be observed in PCV2 infections. Additionally, the macrophages inoculated together with PCV2 also were ineffective in the production of $\mathrm{O}_{2}^{-}$and $\mathrm{H}_{2} \mathrm{O}_{2}$ [33]. The alveolar macrophages can carry PCV2 in infected swines, although do not show direct cytotoxicity, PCV2 can impede the expression capacity of several cytokines associated with the oxygen dependent microbiocidal activity, thus allowing the infection by the secondary or opportunist pathogens [34].

Several authors have shown the necessity of co-infection or the presence of a non-infectious factor for the disease development [13,35]. PMWS has been found in combination with PCV2 infection and other virulent pathogens, such as porcine respiratory and reproductive syndrome virus (PRRSV), swine influenza virus, porcine parvovirus (PPV), Haemophilus parasuis, Actinobacillus pleuropneumoneiae, Streptococcus suis and Mycoplasma hyopneumoniae [36,37]. Such infections can confuse and complicate the clinical representation of the disease. PRRSV was detected in $83 \%$ of the PMWS cases in the Netherlands and in about $52 \%$ of the cases in the USA [20]. Furthermore, it has been shown that PCV2 is mostly associated with PMWS [38] and that PCV2 infection has been implicated in the reduced efficacy of PRRSV vaccine [39].

The manifestation of the clinical signs and lesions associated with PMWS occur in a very light form in SPF piglets infected with PCV2. However, PCV2 was detected in other organs, with higher number of histopathological lesions in a greater proportion of swines coinfected with PPV, than in swines infected only with PCV2 [7,40].

The serological response of infected animals show a decline in the passive antibodies about after 3 but before 11 weeks of life and reappears about at the age of 15 weeks, maintaining high titers till the age of slaughter $[14,41]$. Previous studies have shown that high titer of passive antibodies can impart a certain degree of protection against infections by PCV2 and the clinical disease [42], while the total antibodies remain at levels similar to 
the healthy or PMWS affected animals. But the neutralizing antibodies have lower titers in animals with PMWS [43]. On the other hand, some studies did not show serological differences between healthy and PMWS affected pigs $[44,45]$.

\section{Commercial Vaccines}

Before the development of commercial vaccines, in an attempt to control the disease, veterinaries use to recommend autogenous vaccines. These vaccines formulation basically consisted of macerated tissues of PMWS affected animals that was inactivated by chemical reagents, and then sterilized and applied to 3 to 4 weeks old piglets. The farmers who used to use this vaccine usually reported reduction in mortality. This practice of immunization was well spread in the USA and some European countries. Nevertheless, with the development of commercial vaccines, this sanitary management strategy was abandoned in many countries. Not in the distant past, this system of vaccination to control PCV2 related diseases had been used in Brazil. The disease control done with this vaccine was wide spread in highly technified pig farms, but at the end of the year 2007, the Agricultural and Food Ministry (Ministério da Agricultura, Pecuária e Abastecimento, MAPA), forbided its production and marketing, under the argument that there is no quality control regarding quantification of the viral antigen in different lots, which would lead to unequal field response.

Earlier studies indicate that high levels of antibodies in the vaccinated swine-farms can confer immunity against PCV2 infection and the associated clinical diseases $[42,46,47]$. There are four commercially available vaccines against PCV2 infections in sows and piglets (Table 1). The Circovac ${ }^{\circledR}$ was one of the first vaccines on the market and has been used most extensively in Europe. Circovac ${ }^{\circledR}$ is a vaccine of viral particles of inactive PCV2 developed by Merial for use in sows and piglets. Circo$\mathrm{vac}^{\circledR}$ used in gilts and sows will increase, homogenize and improve specific maternal immunity to PCV2. Transfer of passive immunity from sow to piglet is effective, provided colostrum intake is sufficient [17]. A large scale study was conducted for a 6-month period in France using vaccinated sows in which results were entirely attributeable to pigs born from vaccinated sows. Significant improvements were found in post-weaning mortality rate: from $3.6 \%$ to $2.2 \%$; fattening mortality rate: from $7.2 \%$ to $5.1 \%$; weaning-to-slaughter mortality rate: from $10.6 \%$ to $7.1 \%$, standardized feed efficiency: 2.75 to 2.64 [48].

The vaccine Fort Dodge Suvaxyn ${ }^{\circledR}$ PCV2 One Dose ${ }^{\mathrm{TM}}$ contains inactivated particles of a chimeric virus PCV1-2 [49]. This vaccine was first approved for commercialization in the United States. Both live chimeric virus and the DNA of this construction had their immunogenic potencial evaluated in SPF swines [49]. However, Fort Dodge Animal Health markets this vaccine in form of the dead virus. The commercial inactivated vaccine showed the efficacy in the assays in the naturally infected swine farms [50]. New studies were done in an attempt to show

Table 1. Commercial vaccines used to control the diseases associated with PCV2.

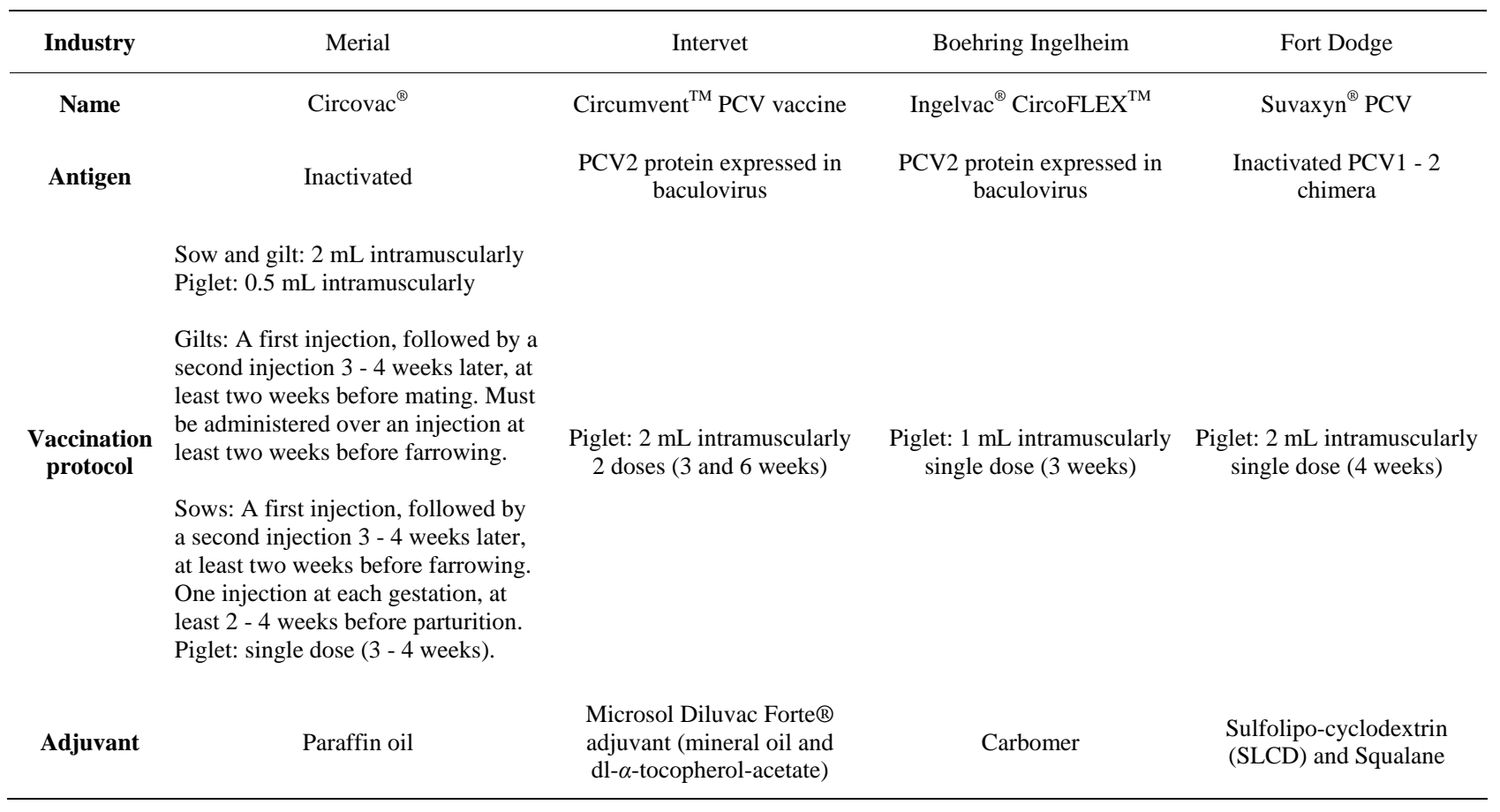


the genetic stability of this live virus, in which no genetic differences were found after 15 passes of the chimeric virus through PK15 cells and three passes through swines. The authors suggested that the live chimeric virus is genetically stable and can be a good candidate for vaccine [51]. The vaccination also showed the efficacy for reducing the viraemia and lesions associated with PCV2 and PRRSV co-infection [52].

Two other commercial vaccines, porcilis ${ }^{\circledR}$ PCV (Intervet Schering-Plough Animal Health) and Ingelvac ${ }^{\circledR}$ Circoflex $^{\mathrm{TM}}$ (Bhoeringer Ingelheim Vertmedica), use the strategy of recombinant production of proteins of the viral capsid in baculovirus. Both the vaccines result in reduction of the viraemia and associated clinical signs of PMWS $[46,47]$. Other studies have shown that this type of recombinant antigen production favors in vitro production of virus-like particles [53]. Virus-like particles (VLPs) are highly repetitive and orderly structured that can trigger potent humoral and extremely powerful cellular responses [54].

The serological profile has been shown to be heterogeneous among swine farms, with coexistence, in the same farm of animals serologically negative and animals with high titers of antibodies. Characterization of serological profiles may provide key information for the adoption of vaccination programs that account for the level and decline of passive immunity as well as the animal age at which clinical signs appear in each farm [55]. The studies have been done in naturally infected swine farms to determine the differences related to the number of vaccine doses. Viraemia was reduced by $78.5 \%$ in pigs vaccinated with one dose of commercial Ingelvac $^{\circledR}$, Circoflex ${ }^{\text {TM }}$ or Suvaxyn ${ }^{\circledR}$ PCV2. Viraemia was lowest to two doses of Suvaxyn ${ }^{\circledR}$ PCV2 and Intervet, in $97.1 \%$ of pigs. Overall microscopic lymphoid lesions were reduced by $78.7 \%$ and $81.8 \%$, respectively [56]. However, future studies need to evaluate the effect of maternal antibodies on the long term efficacy of one and two doses of PCV2 vaccines.

The available commercial vaccines considerably reduce the PCV2 associated clinical disease and mortality, but the vaccinated animals continue to be susceptible to the viral infection and subclinical disease development. Even the vaccinated animals develop discrete lesions of lymphoid depletion that lead to immunodepression, thus opening the opportunity to infections by other pathogens such as PRRSV, Mycoplasma hyopneumoneae and Swine influenza. Therefore, it is necessary to better evaluate the number of doses of each vaccine, taking cost-benefit into account. The question that also need to be resolved is the fact of different farms showing with different serological profiles, since high titer of the antibodies in animal that need to be vaccinated can interfere in the immunization process. The commercial vaccines against PCV2 infec- tion are contributing significantly to control the related diseases, however new field testes should be done to improve their efficacy.

\section{Experimental Vaccines}

The experimental vaccines under development are showing relative success under experimental conditions. In general, this generation of vaccines is being produced by the recombinant DNA technology. The advantage of these vaccines lies in the elimination of biosafety risks associated with the isolation and manipulations of infectious viruses and the use of the inactivated viruses that can lead to vaccine related surge linked to the inactivation failure.

The recombinant vaccines for PCV2 infection, in majority, use genetical manipulation in the sequence of ORF2 nucleotide that contains a region where the immunogenic epitopes of the virus are scripted [57-60]. Certain studies have used the strategy of DNA vaccine using ORF2 as the immunogen [61-64]. The DNA vaccines can be injected with the use of the traditional syringes or inoculated by the use of gene guns. Additionally, these DNA vaccines are more stable in the environmental conditions than the conventional vaccines [65]. It allows for the use of a more pure immunogen, and easy purification of plasmidial preparations, and ability of inducing immunity even in the presence of maternal antibodies [66,67].

Different from inactivated or subunit vaccines, DNA vaccines may result in an antigenic presentation via class I and class II MHC molecules, which mimics the resulting immune response related to natural infection, stimulating $\mathrm{CD}^{+}$and $\mathrm{CD}^{+} \mathrm{T}$ lymphocytes and antibody production. This vaccine strategy can thus stimulate potent cellular and humoral response $[68,69]$. We recently described the construction of a recombinant plasmid that expresses PCV2 structural protein (encoded by ORF2) and evaluated the cellular and humoral immune response against this recombinant vaccine in BALB/c mice, where it showed the capacity to induce cellular and humoral response in inoculated mice [64].

Other experimental vaccines are being developed, including a recombinant adenovirus expressing the ORF2 protein [70]. Other systems used adenovirus as a vector for short-hairpin interference RNAs target to decrease the ORF1 and ORF2 transcription in vitro analyses [71]. The use of adenovirus as vector is sustained, especially by its capacity to infect a large variety of cells, regardless of the cell cycle stage. This fact, in addition to the ease of production and purification make it an interesting model [71]. The genome of adenovirus can incorporate about 2 $\mathrm{Kb}$ of DNA sequence without losing its stability and viability. To add larger DNA fragments it is essential to delete a part of the viral genome [72]. The majority of 
the recombinant adenovirus so far produced have genes responsible for replication deleted, thus not disallowing the recombinant virus to replicate in the immunized animal $[73,74]$. Recently our research group constructed a recombinant adenovirus that expresses the PCV2 viral capsid protein, and the initial testes in Balb/c mice have shown good results regarding cellular and humoral response [75].The recombinant virus of pseudorabies (PR) expressing the fused ORF1 and ORF2 [76] or ORF2 alone has been used in vaccine tests [77]. The PR is an important disease of swines and other species with high negative impact on the swine husbandry worldwide [78]. The attenuated PR virus is a promising live vector for multivalent vaccines against PR and other viral swine diseases [79]. The PRV genome consists of a linear DNA tape, while in the recombinant viruses the regions linked to the virulence such as thymidine kinase (TK), glicoproteíns (gE, gI) have been removed [78]. Thus, it is possible that a vaccine of recombinant PRV expressing the ORF2 would be bivalent against the field PR virus and PCV2 [77].

Other systems have used PCV2 capsid protein expression in Lactococcus lactis as a method to obtain the antigen for oral immunization [80]. The use of L. lactis as a candidate for oral vaccine is favored for being generally regards as safe -GRAS- [81].

This new generation of vaccines shows the development of potent vaccine candidates, because they take into account the manipulation of the genomic fragments responsible for the pathogenicity and immunity, assuring greater immunogenicity and vaccine security. However, it still depends on the elucidation of the biosafety aspects, for large scale production and experimental evaluation in swine and field tests.

\section{Acknowledgements}

The FAPEMIG and CNPq project financial support is from production of vaccines against PCV2 group studying.

\section{REFERENCES}

[1] P. D. Lukert, G. F. De Boer, J. L. Dale, P. Keese, M. S. Mcnulty, J. W. Randles and I. Tischer, "The Circoviridae,” In: F. A. Murphy, C. M. Fauquet, D. H. L. Bishop, S. A. Ghabrial, G. P. Martelli, M. A. Mayo and M. D. Summers, Eds., Virus Taxonomy: Six Report of the International Committee on Taxonomy of Viruses, Springer Verlag, New York, 1995, pp. 166-168.

[2] I. Morozov, T. Sirinarumitr, S. D. Sorden, P. G. Halbur, M. K. Morgan, K. J. Yoon and P. S. Paul, "Detection of a Novel Strain of Porcine Circovirus in Pigs with Postweaning Multisystemic Wasting Syndrome,” Journal of Clinical Microbiology, Vol. 36, No. 9, 1998, pp. 25352541.
[3] J. Liu, I. Chen, Q. Du, H. Chua and J. Kwang, “The ORF3 Protein of Porcine Circovirus Type 2 Is Involved in Viral Pathogenesis in Vivo," Journal of Virology, Vol. 80, No. 10, 2006, pp. 5065-5073. doi:10.1128/JVI.80.10.5065-5073.2006

[4] A. K. Karuppannan, M. H. Jong, S.-H Lee, Y. Zhu, M. Selvaraj, J. Lau, Q. Jia and J. Kwang, "Attenuation of Porcine Circovirus 2 in SPF Piglets by Abrogation of ORF3 Function,” Virology, Vol. 383, No. 2, 2009, pp. 338-347. doi:10.1016/j.virol.2008.10.024

[5] I. Tischer, R. Rasch and G. Tochtermann, "Characterization of Papovavirus and Picornavirus-Like Particles in Permanent Pig Kidney Cell Line,” Zentralblatt für Bakteriologie, Vol. 226, No. 2, 1974, pp. 153-167.

[6] J. Segalés, G. M. Allan and M. Domingo, "Porcine Circovirus Diseases," Animal Health Research Reviews, Vol. 6, No. 2, 2005, pp. 119-142. doi:10.1079/AHR2005106

[7] G. M. Allan and J. A. Ellis, "Porcine Circoviruses: A Review," Journal of Veterinary Diagnostic Investigation, Vol. 12, No. 1, 2000, pp. 3-14. doi:10.1177/104063870001200102

[8] T. Opriessnig, X. J. Meng and P. G. Halbur, "Porcine Circovirus Type 2 Associated Disease: Update on Current Terminology, Clinical Manifestations, Pathogenesis, Diagnosis, and Intervention Strategies," Journal of Veterinary Diagnostic Investigation, Vol. 19, No. 6, 2007, pp. 591-615. doi:10.1177/104063870701900601

[9] A. Olvera, M. Cortey and J. Segalés, "Molecular Evolution of Porcine Circovirus Type 2 Genomes: Phylogeny and Clonality," Virology, Vol. 357, No. 2, 2007, pp. 175185. doi:10.1016/j.virol.2006.07.047

[10] D. J. An, I. S. Roh, D. S. Song, C. K. Park and B. K. Park, "Phylogenetic Characterization of Porcine Circovirus Type 2 in PMWS and PDNS Korean Pigs between 1999 and 2006," Virus Research, Vol. 129, No. 2, 2007, pp. 115-122. doi:10.1016/j.virusres.2007.06.024

[11] L. Grau-Roma, E. Crisci, M. Sibila, S. Lopez-Soria, M. Nofrarias, M. Cortey, L. Fraile, A. Olvera and J. Segalés, “A Proposal on Porcine Circovirus Type 2 (PCV2) Genotype Definition and Their Relation with Postweaning Multisystemic Wasting Syndrome (PMWS) Occurrence," Veterinary Microbiology, Vol. 128, No. 1-2, 2008, pp. 23-35. doi:10.1016/j.vetmic.2007.09.007

[12] O. Chiarelli-Neto, K. S. C. Yotoko, P. M. P. Vidigal, F. M. F. Silva, L. A. Castro, J. L. R. Fietto, A. Silva Jr. and M. R. Almeida, "Classification and Putative Origins of Brazilian Porcine Circovirus 2 Inferred through Phylogenetic and Phylogeographical Approaches," Virus Research, Vol. 140, No. 1-2, 2009, pp. 57-63.

doi:10.1016/j.virusres.2008.11.002

[13] G. M. Allan, S. Kennedy, F. McNeilly, J. C. Foste, J. A. Ellis, S. J. Krakowka, B. M. Meehan and B. M. Adair, "Experimental Reproduction of Severe Wasting Disease by Co-Infection of Pigs with Porcine Circovirus and Porcine Parvovirus," Journal of Comparative Pathology, Vol. 121, No. 1, 1999, pp. 1-11. doi:10.1053/jcpa.1998.0295

[14] G. M. Rodríguez-Arrioja, J. Segalés, M. Calsamiglia, A. R. Resendes, M. Balasch, J. Plana-Duran, J. Casal and M. Domingo, "Dynamics of Porcine Circovirus Type 2 Infec- 
tion in a Herd of Pigs with Postweaning Multisystemic Wasting Syndrome," American Journal of Veterinary Research, Vol. 63, No. 3, 2002, pp. 354-357.

doi:10.2460/ajvr.2002.63.354

[15] F. C. Hasslung, M. Berg, G. M. Allan, B. M. Meehan, F. McNeilly and C. Fossum, "Identification of a Sequence from the Genome of Porcine Circovirus Type 2 with an Inhibitory Effect on IFN- $\alpha$ Production by Porcine PBMCs," Journal of General Virology, Vol. 84, No. 11, 2003, pp. 2937-2945. doi:10.1099/vir.0.19362-0

[16] H. S. Cho, T. J. Kim, J. I. Lee and N. Y. Park, "Serodiagnostic Comparison of Enzyme-Linked Immunosorbent Assay and Surface Plasmon Resonance for the Detection of Antibody to Porcine Circovirus Type 2," Canadian Journal of Veterinary Research, Vol. 70, No. 4, 2006, pp. 263-268.

[17] F. Joisel, C. Charreyre, E. Bordin and S. Longo, "Vaccination of Sows and Gilts against PCV2 Diseases: Field Experiences in Europe and Canada," Proceeding of the XIII Brazilian Congress of Veterinary Specialists in Pigs (ABRAVES), Florianópolis, 26-29 October 2007, pp. 1729.

[18] J. R. Kolb, "Ingelvac ${ }^{\circledR}$ Circoflex $^{\mathrm{TM}}$ Vaccine Against PCV2 Virus," Proceedings of the XIII Brazilian Congress of Veterinary Specialists in Pigs (ABRAVES), Florianópolis, 26-29 October 2007, pp. 239-245.

[19] M. Fenaux, T. Opriessnig, P. G. Halbur, F. Elvinger and X. J. Meng, "A Chimeric Porcine Circovirus (PCV) with the Immunogenic Capsid Gene of the Pathogenic PCV Type 2 (PCV-2) Cloned into the Genomic Backbone of the Nonpathogenic PCV-1 Induces Protective Immunity against PCV2 Infection in Pigs,” Journal of Virology, Vol. 78, No. 12, 2004, pp. 6297-6303. doi:10.1128/JVI.78.12.6297-6303.2004

[20] S. Ramamoorthy and X. J. Meng, "Porcine Circoviruses: A Minuscule yet Mammoth Paradox," Animal Health Research Reviews, Vol. 10, No. 1, 2008, pp. 1-20. doi:10.1017/S1466252308001461

[21] J. Segalés, F. Alonso, C. Rosell, J. Pastor, F. Chianini, E. Campos, L. Lopez-Fuertes, J. Quintana, G. RodriguezArrioja, M. Calsamiglia, J. Pujols, J. Dominguez and M. Domingo, "Changes in Peripheral Blood Leukocyte Populations in Pigs with Natural Postweaning Multisystemic Wasting Syndrome (PMWS)," Veterinary Immunology and Immunopathology, Vol. 81, No. 1-2, 2001, pp. 37-44. doi:10.1016/S0165-2427(01)00326-9

[22] L. Darwich, J. Segales, M. Domingo and E. Mateu, "Changes in $\mathrm{CD}^{+}, \mathrm{CD}^{+}, \mathrm{CD}^{+} / \mathrm{CD}^{+}$, and Immunoglobulin M-Positive Peripheral Blood Mononuclear cells of Postweaning Multisystemic Wasting Syndrome-Affected Pigs Andage-Matched Uninfected Wasted and Healthy Pigs Correlate with Lesions and Porcine Circovirus Type 2 Load in Lymphoid Tissues," Clinical and Vaccine Immunology, Vol. 9, No. 2, 2002, pp. 236-242. doi:10.1128/CDLI.9.2.236-242.2002

[23] S. S. Grierson, D. P. King, A. W Tucker, M. Donadeu, M. A. Mellencamp, K. Haverson, M. Banks and M. Bailey, "Ontogeny of Systemic Cellular Immunity in the Neonatal Pig: Correlation with the Development of Post-Weaning Multisystemic Wasting Syndrome," Veterinary Im- munology and Immunopathology, Vol. 119, No. 3-4, 2007, pp. 254-268. doi:10.1016/j.vetimm.2007.06.004

[24] W. Sipos, J. C. Duvigneau, M. Willheim, F. Schilcher, R. T. Hartl, G. Hofbauer, B. Exel, P. Pietschmann and F. Schmoll, "Systemic Cytokine Profile in Feeder Pigs Suffering from Natural Postweaning Multisystemic Wasting Syndrome (PMWS) as Determined by Semiquantitative RT-PCR and Flow Cytometric Intracellular Cytokine Detection," Veterinary Immunology and Immunopathology, Vol. 99, No. 1-2, 2004, pp. 63-71. doi:10.1016/j.vetimm.2004.01.001

[25] J. Nielsen, I. E. Vincent, A. Botner, A. S. LadekaerMikkelsen, G. Allan, A. Summerfield and K. C. McCullough, "Association of Lymphopenia with Porcine Circovirus Type 2 Induced Postweaning Multisystemic Wasting Syndrome (PMWS)," Veterinary Immunology and Immunopathology, Vol. 92, No. 3-4, 2003, pp. 97-111. doi:10.1016/S0165-2427(03)00031-X

[26] P. Meerts, G. Misinzo and H. J. Nauwynck, "Enhancement of Porcine Circovirus 2 Replication in Porcine Cell Lines by IFN-Gamma before and after Treatment and by IFN- $\alpha$ after Treatment," Journal of Interferon \& Cytokine Research, Vol. 25, No. 11, 2005, pp. 684-693. doi:10.1089/jir.2005.25.684

[27] G. Misinzo, P. L. Delputte, D. J. Lefebvre and H. J. Nauwynck, "Increased Yield of Porcine Circovirus-2 by a Combined Treatment of PK-15 Cells with InterferonGamma and Inhibitors of Endosomal Lysosomal System Acidification," Archives of Virology, Vol. 153, No. 2, 2008, pp. 337-342. doi:1854/10516

[28] I. E. Vincent, C. Balmelli, B. Meehan, G. Allan, A. Summerfield and K. C. McCullough, "Silencing of Natural Interferon Producing Cell Activation by Porcine Circovirus Type 2 DNA,” Immunology, Vol. 120, No. 1, 2007, pp. 47-56. doi:10.1111/j.1365-2567.2006.02476.x

[29] W. Sipos, J. C. Duvigneau, P. Pietschmann, F. Schilcher, G. Hofbauer, R. T. Hartl and F. Schmoll, "Porcine Dermatitis and Nephropathy Syndrome (PDNS) Is Associated with a Systemic Cytokine Expression Profile Indicative of Proinflammation and a Th1 Bias," Veterinary Immunology and Immunopathology, Vol. 107, No. 3-4, 2005, pp. 303-313. doi:10.1016/j.vetimm.2005.05.003

[30] J. Kim and C. Chae, "Expression of Monocyte Chemoattractant Protein-1 and Macrophage Inflammatory Protein1 in Porcine Circovirus 2-Induced Granulomatous Inflammation," Journal of Comparative Pathology, Vol. 131, No. 2-3, 2004, pp. 121-126. doi:10.1016/j.jcpa.2004.02.001

[31] G. Sarli, L. Mandrioli, M. Laurenti, L. Sidoli, C. Cerati, G. Rolla and P. S. Marcato, "Immunohistochemical Characterization of the Lymph Node Reaction in Pig PostWeaning Multisystemic Wasting Syndrome (PMWS)," Veterinary Immunology and Immunopathology, Vol. 83, No. 1-2, 2001, pp. 53-67. doi:10.1016/S0165-2427(01)00363-4

[32] M. Kiupel, G. W. Stevenson, E. J. Galbreath, A. North, H. HogenEsch and S. K. Mittal, "Porcine Circovirus Type 2 (PCV2) Causes Apoptosis in Experimentally Inoculated BALB/c Mice," BMC Veterinary Research, Vol. 1, No. 7, 2005, pp. 1-8. 
[33] H. W. Chang, C. R. Jeng, J. J. Liu, T. L. Lin, C. C. Chang, M. Y. Chia, Y. C. Tsai and V. F. Pang, "Reduction of Porcine Reproductive and Respiratory Syndrome Virus (PRRSV) Infection in Swine Alveolar Macrophages by Porcine Circovirus 2 (PCV2)-Induced Interferon- $\alpha$," Veterinary Microbiology, Vol. 108, No. 3-4, 2005, pp. 167177. doi:10.1016/j.vetmic.2005.03.010

[34] H. W. Chang, C. R. Jeng, T. L. Lin, J. J. Liu, M. Y. Chia, Y. C. Tsai and V. F. Pang, "Immunopathological Effects of Porcine Circovirus Type 2 (PCV2) on Swine Alveolar Macrophages by in Vitro Inoculation," Veterinary Immunology and Immunopathology, Vol. 110, No. 3-4, 2006, pp. 207-219. doi:10.1016/j.vetimm.2005.09.016

[35] C. Choi and C. Chae, "Distribution of Porcine Parvovirus in Porcine Circovirus 2 Infected Pigs with Postweaning Multisystemic Wasting Syndrome as Shown by in-Situ Hybridization," Journal of Comparative Pathology, Vol. 123, No. 4, 2000, pp. 302-305. doi:10.1053/jсра.2000.0421

[36] J. Kim, H. K. Chung, T. Jung, W. S. Cho, C. Choi and C. Chae, "Postweaning Multisystemic Wasting Syndrome of Pigs in Korea: Prevalence, Microscopic Lesions and CoExisting Microorganisms," Journal of Veterinary Medical Science, Vol. 64, No. 1, 2002, pp. 57-62. doi:10.1292/jvms.64.57

[37] F. J. Pallares, P. G. Halbur, T. Opriessnig, S. D. Sorden, D. Villar, B. H. Janke, M. J. Larson, K. J. Schwartz, K. J. Yoon and L. J. Hoffman, "Porcine Circovirus Type 2 (PCV-2) Coinfections in US Field Cases of Postweaning Multisystemic Wasting Syndrome (PMWS)," Journal of Veterinary Diagnostic Investigation, Vol. 14, No. 6, 2002, pp. 515-519. doi:10.1177/104063870201400614

[38] R. M. Pogranichniy, K. J. Yoon, P. A. Harms, S. D. Sorden and M. Daniels, "Case-Control Study on the Association of Porcine Circovirus Type 2 and other Swine Viral Pathogens with Postweaning Multisystemic Wasting Syndrome," Journal of Veterinary Diagnostic Investigation, Vol. 14, No. 6, 2002, pp. 449-456. doi:10.1177/104063870201400601

[39] T. Opriessnig, N. E. McKeown, K. L. Harmon, X. J. Meng and P. G. Halbur, "Porcine Circovirus Type 2 Infection Decreases the Efficacy of a Modified Live Porcine Reproductive and Respiratory Syndrome Virus Vaccine,” Clinical and Vaccine Immunology, Vol. 13, No. 8, 2006, pp. 923-929. doi:10.1128/CVI.00074-06

[40] L. T. Fernandes, J. R. Ciacci-Zanella, J. Sobestiansky, M. Schiochet and C. Trombetta, "Coinfecção Experimental de Circovírus Suíno Tipo 2 (PCV2) Isolado no Brasil e Parvovírus Suíno (PPV) em Auínos SPF," Arquivo Brasileiro de Medicina Veterinária e Zootecnia, Vol. 58, No. 1, 2006, pp. 1-8. doi:10.1590/S0102-09352006000100001

[41] N. E. McKeown, T. Opriessnig, P. Thomas, D. K. Guenette, F. Elvinger, M. Fenaux, P. G. Halbur and X. J. Meng, "Effects of Porcine Circovirus Type 2 (PCV2) Maternal Antibodies on Experimental Infection of Piglets with PCV2," Clinical and Vaccine Immunology, Vol. 12, No. 11, 2005, pp. 1347-1351. doi:10.1128/CDLI.12.11.1347-1351.2005

[42] M. Calsamiglia, L. Fraile, A. Espinal, A. Cuxart, C. Semi- nati, M. Martin, E. Mateu and J. Segalés, "Sow Porcine Circovirus Type-2 (PCV2) Status Effect on Litter Mortality in Post-Weaning Multisystemic Wasting Syndrome (PMWS)," Research in Veterinary Science, Vol. 82, No. 3, 2007, pp. 299-304. doi:10.1016/j.rvsc.2006.08.007

[43] M. Fort, A. Olvera, M. Sibila, J. Segalés and E. Mateu, "Detection of Neutralizing Antibodies in Postweaning Multisystemic Wasting Syndrome (PMWS)-Affected and Non-PMWS-Affected Pigs," Veterinary Microbiology, Vol. 125, No. 3-4, 2007, pp. 244-255. doi:10.1016/j.vetmic.2007.06.004

[44] R. Larochelle, R. Magar and S. D’Allaire, "Comparative Serologic and Virologic Study of Commercial Swine Herds with and without Postweaning Multisystemic Wasting Syndrome," Canadian Journal of Veterinary Research, Vol. 67, No. 2, 2003, pp. 114-120.

[45] M. Sibila, M. Calsamiglia, J. Segalés, P. Blanchard, L. Badiella, M. Le Dimna, A. Jestin and M. Domingo, "Use of a Polymerase Chain Reaction Assay and an ELISA to Monitor Porcine Circovirus Type 2 Infection in Pigs from Farms with and without Postweaning Multisystemic Wasting Syndrome," American Journal of Veterinary Research, Vol. 65, No. 1, 2004, pp. 88-92. doi:10.2460/ajvr.2004.65.88

[46] M. Kixmoller, M. Ritzmann, M. Eddicks, A. Saalmuller, K. Elbersa and V. Fachinger, "Reduction of PMWS-Associated Clinical Signs and Co-Infections by Vaccination against PCV2," Vaccine, Vol. 26, No. 27-28, 2008, pp. 3443-3451. doi:10.1016/j.vaccine.2008.04.032

[47] M. Fort, M. Sibila, E. Pérez-Martín, M. Nofrarías, E. Mateu and J. Segalés, "One Dose of a Porcine Circovirus 2 (PCV2) Sub-Unit Vaccine Administered to 3-Week-Old Conventional Piglets Elicits Cell-Mediated Immunity and Significantly Reduces PCV2 Viremia in an Experimental Model," Vaccine, Vol. 27, No. 30, 2009, pp. 4031-4037. doi:10.1016/j.vaccine.2009.04.028

[48] J. B. Hérin, B. Fily, S. Longo and F. Joisel, "Field Results of the Use of Circovac ${ }^{\circledR}$ a Sow PCV2 Vaccine in France under Provisional Registration," Proceedings of the 5th International Symposium on Emerging and Re-Emerging Pig Diseases, 24-27 June 2007, Krakow, p. 125.

[49] M. Fenaux, T. Opriessnig, P. G. Halbur and X. J. Meng, "Immunogenicity and Pathogenicity of Chimeric Infectious DNA Clones of Pathogenic Porcine Circovirus Type 2 (PCV2) and Nonpathogenic PCV1 in Weanling Pigs," Journal of Virology, Vol. 77, No. 20, 2003, pp. 1123211243. doi:10.1128/JVI.77.20.11232-11243.2003

[50] E. C. Doornenbal, "Field Efficacy of Suvaxyn PCV2 one Dose," Proceedings of the XIII Brazilian Congress of Veterinary Specialists in Pigs (ABRAVES), Florianópolis, 26-29 October 2007, pp. 37-43.

[51] J. Gillespie, N. M. Juhan, J. DiCristina, K. F. Key, S. Ramamoorthy and X. J. Meng, "A Genetically Engineered Chimeric Vaccine against Porcine Circovirus Type 2 (PCV2) Is Genetically Stable in Vitro and in Vivo," Vaccine, Vol. 26, No. 33, 2008, pp. 4231-4236. doi:10.1016/j.vaccine.2008.05.051

[52] T. Opriessnig, A. R. Patterson, J. Elsener, X. J. Meng and P. G. Halbur, "Influence of Maternal Antibodies on Effi- 
cacy of Porcine Circovirus Type 2 (PCV2) Vaccination to Protect Pigs from Experimental Infection with PCV2,” Clinical and Vaccine Immunology, Vol. 15, No. 3, 2008, pp. 397-401. doi:10.1128/CVI.00416-07

[53] H. Fan, C. Ju, T. Tong, H. Huang, J. Lv and H. Chen, "Immunogenicity of Empty Capsids of Porcine Circovius Type 2 Produced in Insect Cells," Veterinary Research Communications, Vol. 31, No. 4, 2007, pp. 487-496. doi:10.1007/s11259-007-3469-7

[54] F. Boisgérault, G. Moron and C. Leclerc, "Virus-Like Particles: A New Family of Delivery Systems," Expert Review of Vaccines, Vol. 1, No. 1, 2002, pp. 101-109. doi:10.1586/14760584.1.1.101

[55] P. F. Gerber, G. C. F. Galinari, M. X. Silva, F. S. Campos, A. C. T. Reis and Z. I. P. Lobato, "Distribution of Antibodies against Porcine Circovirus Type-2 (PCV2) in Single Site and Multi-Site Farrow-to-Finish Farms in Brazil,” Research in Veterinary Science, Vol. 87, No. 3, 2009, pp. 488-491.doi:10.1016/j.rvsc.2009.04.013

[56] T. Opriessnig, A. R. Patterson, D. M. Madson, N. Pal and P. G. Halbur, "Comparison of Efficacy of Commercial One Dose and Two Dose PCV2 Vaccines Using a Mixed PRRSV-PCV2-SIV Clinical Infection Model 2-3-Months Post Vaccination," Vaccine, Vol. 27, No. 7, 2009, pp. 1002-1007. doi:10.1016/j.vaccine.2008.11.105

[57] D. Mahé, P. Blanchard, C. Truong, C. Arnauld, P. Cann, R. Cariolet, F. Madec, E. Albina and A. Jestin, "Differential Recognition of ORF2 Protein from Type 1 and Type 2 Porcine Circoviruses and Identification of Immunorelevant Epitopes,” Journal of General Virology, Vol. 81, No. 7, 2000, pp. 1815-1824.

[58] C. Truong, D. Mahe, P. Blanchard, M. Le Dimna, F. Madec, A. Jestin and E. Albina, "Identification of an Immunorelevant ORF2 Epitope from Porcine Circovirus Type 2 as a Serological Marker for Experimental and Natural Infection,” Archives of Virology, Vol. 146, No. 6, 2001, pp. 1197-1211. doi:10.1007/s007050170115

[59] P. Lekcharoensuk, I. Morozov, P. S. Paul, N. Thangthumniyom, W. Wajjawalku and X. J. Meng, "Epitope Mapping of the Major Capsid Protein of Type 2 Porcine Circovirus (PCV2) by Using Chimeric PCV1 and PCV2," Journal of Virology, Vol. 78, No. 15, 2004, pp. 81358145. doi:10.1128/JVI.78.15.8135-8145.2004

[60] S.-B. Shang, Y.-L. Jin, X.-T. Jianga, J.-Y. Zhoua, X. Zhanga, G. Xing, J.-L. He and Y. Yan, "Fine Mapping of Antigenic Epitopes on Capsid Proteins of Porcine Circovirus and Antigenic Phenotype of Porcine Circovirus Type 2," Molecular Immunology, Vol. 46, No. 3, 2009, pp. 327-334. doi:10.1016/j.molimm.2008.10.028

[61] P. Blanchard, D. Mahé, R. Cariolet, A. Keranflec’h , M. A. Baudouard, P. Cordioli, E. Albina and A. Jestin, "Protection of Swine against Post-Weaning Multisystemic Wasting Syndrome (PMWS) by Porcine Circovirus Type 2 (PCV2) Proteins,” Vaccine, Vol. 21, No. 31, 2003, pp. 4565-4575. doi:10.1016/S0264-410X(03)00503-6

[62] S. Kamstrup, A. M. Barfoed, T. H. Frimann, A. S. Ladekjaer-Mikkelsen and A. Botner, "Immunisation against PCV2 Structural Protein by DNA Vaccination of Mice,” Vaccine, Vol. 22, No. 11-12, 2004, pp. 1358-1361. doi:10.1016/j.vaccine.2004.01.032

[63] K. Aravindaram, T.-Y Kuo, C.-W Lan, H.-H Yu, P.-H Wang, Y.-S Chen, G. H.-C. Chen and N.-S Yang, "Protective Immunity against Porcine Circovirus 2 in Mice Induced by a Gene-Based Combination Vaccination,” Journal of Gene Medicine, Vol. 11, No. 4, 2009, pp. 288301.

[64] A. Silva Jr., L. A. Castro, O. Chiarelli-Neto, F. M. F. Silva, P. M. P. Vidigal, M. P. Moraes and M. R. Almeida, "Development and Evaluation of a Recombinant DNA Vaccine Candidate Expressing Porcine Circovirus 2 Structural Protein,” Pesquisa Veterinária Brasileira, Vol. 29, No. 1, 2009, pp. 76-82. doi:10.1590/S0100-736X2009000100012

[65] H. Shams, "Recent Developments in Veterinary Vaccinology," Veterinary Journal, Vol. 170, No. 3, 2005, pp. 289-299. doi:10.1016/j.tvjl.2004.07.004

[66] D. E. Hassett, J. Zhang and J. L. Whitton, "Neonatal DNA Immunization with a Plasmid Encoding an Internal Viral Protein Is Effective in the Presence of Maternal Antibodies and Protects against Subsequent Viral Challenge,” Journal of Virology, Vol. 71, No. 10, 1997, pp. 7881-7888.

[67] L. Fischer, S. Barzu, C. Andreoni, N. Buisson, A. Brun and J. C. Audonnet, "DNA Vaccination of Neonate Piglets in the Face of Maternal Immunity Induces Humoral Memory and Protection against a Virulent Pseudorabies Virus Challenge," Vaccine, Vol. 21, No. 15, 2003, pp. 1732-1741.

[68] J. B. Ulmer, J. C. Sadoff and M. A. Liu, "DNA Vaccines," Current Opinion in Immunology, Vol. 8, No. 4, 1996, pp. 531-536.

[69] L. A. Babiuk, L.-V Van Drunen, S. Den Hurk, B. I. Loehr and R. Uwiera, "Veterinary Applications of DNA Vaccines,” Developments in Biologicals, Vol. 104, No. 104, 2000, pp. 73-81.

[70] X. Wang, P. Jiang, Y. Li, W. Jiang and X. Dong, "Protection of Pigs against Post-Weaning Multisystemic Wasting Syndrome by a Recombinant Adenovirus Expressing the Capsid Protein of Porcine Circovirus Type 2," Veterinary Microbiology, Vol. 121, No. 3-4, 2007, pp. 215-224. doi:10.1016/j.vetmic.2006.11.027

[71] Z. Feng, P. Jiang, X. Wang, Y. Li and W. Jiang, “Adenovirus-Mediated shRNA Interference against Porcine Circovirus Type 2 Replication both in Vitro and in Vivo," Antiviral Research, Vol. 77, No. 3, 2008, pp. 186-194.

[72] F. Tashiro, H. Niwa and J. I. Miyazaki, “Constructing Adenoviral Vectors by Using the Circular Form of the Adenoviral Genome Cloned in a Cosmid and the CreLoxp Recombinant System," Human Gene Therapy, Vol. 10, No. 11, 1999, pp. 1845-1852. doi:10.1089/10430349950017527

[73] M. Lusky, M. Christ, K. Rittner, A. Dierterlr, D. Dreyer, B. Mourot, H. Schultz, F. Stoeckel, A. Pavirani and M. Mehtali, "In Vitro and in Vivo Biology of Recombinant Adenovirus Vectors with E1, E1/E2A, or E1/E4 Deleted,” Journal of Virology, Vol. 72, No. 3, 1998, pp. 1396-1405.

[74] J. W. Moorhead, G. H. Clayton, R. L. Smith and J. Schaack, “A Replication-Incompetent Adenovirus Vector 
with the Preterminal Protein Gene Deleted Efficiently Transduces Mouses Ears," Journal of Virology, Vol. 73, No. 2, 1999, pp. 1046-1053.

[75] O. Chiarelli-Neto, “Caracterização Imunológica de um Adenovírus Recombinante que Expressa a Proteína do Capsídeo do Circovírus Suíno 2,” Mastet’s Thesis, Federal University of Viçosa, Viçosa, 2009.

[76] C. Ju, H. Fan, Y. Tan, Z. Liu, X. Xi, S. Cao, B. Wu and H. Chen, "Immunogenicity of a Recombinant Pseudorabies Virus Expressing ORF1-ORF2 Fusion Protein of Porcine Circovirus Type 2,” Veterinary Microbiology, Vol. 109, No. 3-4, 2005, pp. 179-190. doi:10.1016/j.vetmic.2005.06.001

[77] Y. Song, M. Jin, S. Zhang, X. Xu, S. Xiao, S. Cao and H. Chen, "Generation and Immunogenicity of a Recombinant Pseudorabies Virus Expressing Cap Protein of Porcine Circovirus Type 2," Veterinary Microbiology, Vol. 119, No. 2-4, 2007, pp. 97-104. doi:10.1016/j.vetmic.2006.08.026

[78] L. E. Pomeranz, A. E. Reynolds and C. J. Hengartner, "Molecular Biology of Pseudorabies Virus: Impact on
Neurovirology and Veterinary Medicine,” Microbiology and Molecular Biology Reviews, Vol. 69, No. 3, 2005, pp. 462-500. doi:10.1128/MMBR.69.3.462-500.2005

[79] M. Van Zijl, L. G. Wensvoort, E. De Kluyver, M. Huls, H. Van der Gulden, A. Gielkens, A. Berns, I. E. Vincent, C. Balmelli, B. Meehan, G. Allan, A. Summerfield and K. C. McCullough, "Silencing of Natural Interferon Producing Cell Activation by Porcine Circovirus Type 2 DNA," Immunology, Vol. 120, No. 1, 2007, pp. 47-56. doi:10.1111/j.1365-2567.2006.02476.x

[80] K. Wang, L. Huang, J. Kong and X. Zhang, “Expression of the Capsid Protein of Porcine Circovirus Type 2 in Lactococcus lactis for Oral Vaccination,” Journal of Virological Methods, Vol. 150, No. 1-2, 2008, pp. 1-6. doi:10.1016/j.jviromet.2008.02.014

[81] S. Drouault, G. Corthier, S. D. Ehrlich and P. Renault, "Survival, Physiology, and Lysis of Lactococcus lactis in the Digestive Tract," Applied and Environmental Microbiology, Vol. 65, No. 11, 1999, pp. 4881-4886. 